\title{
77. BIOSTRATIGRAPHIC AND BIOCHRONOLOGIC SYNTHESIS OF LEGS 127 AND 128: SEA OF JAPAN $^{1}$
}

\author{
L. H. Burckle, ${ }^{2}$ C. A. Brunner ${ }^{3}$ J. Alexandrovich, ${ }_{9}^{4}$ P. DeMenocal, ${ }^{2}$ J. Briscoe ${ }^{5}$ Y. Hamano ${ }_{12}^{6}$ L. Heusser, ${ }^{2}$ J. C. Ingle, Jr., \\ T. Kheradyar, I. Koizumi, ${ }^{8}$ K.A.O. Krumsiek, ${ }^{9}$ H.-Y. Ling, ${ }^{10}$ J. P. Muza, ${ }^{11}$ A. Rahamn, ${ }^{12}$ A. Sturz, ${ }^{13}$ L. Vigliotti, ${ }^{14}$ \\ L. D. White, ${ }^{15}$ J.J.M. Wippern, ${ }^{16}$ and T. Yamanoi ${ }^{17}$
}

\begin{abstract}
This paper summarizes the biostratigraphic and magnetostratigraphic results from the recovery of holes drilled during Legs 127 and 128 in the Sea of Japan. Siliceous microfossils (i.e., diatoms, radiolarians, silicoflagellates, and ebridians) were most useful as biostratigraphic datum markers in the upper part of the section (Pliocene-Pleistocene), as was the magnetostratigraphy. Time series of other biostratigraphic, climatostratigraphic, and lithostratigraphic markers indicate that a high-resolution picture of the late Pliocene-Pleistocene oceanographic and climatic history of the Sea of Japan is possible. These data include coiling direction changes in Neogloboquadrina pachyderma, oxygen isotopes, percent opal, and alternating dark/light rhythms. Although the magnetostratigraphy was somewhat ambiguous in corroborating age determinations in the older part of the sections, calcareous microfossils and foraminifers indicate that some of the holes penetrated as far back in time as the early Miocene. These data provide a new time frame for theories on the age of formation and early history of the Sea of Japan.
\end{abstract}

\section{INTRODUCTION}

Ocean Drilling Program (ODP) Legs 127 and 128 were designed to sample the sediments from what is considered to be a prime example of a backarc basin. These legs were intended (1) to determine the style and dynamics of formation of a marginal sea within the tectonic context of a continental arc and (2) as, presumably, major tectonic, depositional, and climatic events unfolded to determine the concomitant sedimentary and paleoceanographic responses within this region. During Leg 127 four sites (794, 795, 796, and 797) were occupied in the central eastern and northeastern part of the Sea of Japan whereas during Leg 128 two sites (798 and 799) were occupied in the central and southeastern part and Site 794 was reoccupied in order to penetrate farther into a Miocene volcanic basement sequence. The intent of the deeper holes was to realize another objective of the two legs: determination of the time of formation of the Sea of Japan.

An important, although unstated, consideration involved questions concerning the utility of magnetostratigraphy and biostratigra-

\footnotetext{
' Tamaki, K., Suyehiro, K., Allan, J., McWilliams, M., et al., 1992. Proc. ODP, Sci. Results, 127/128, Pt. 2: College Station, TX (Ocean Drilling Program).

${ }^{2}$ Lamont-Doherty Geological Observatory, Palisades, NY 10964, U.S.A

${ }^{3}$ Center for Marine Science, University of Southern Mississippi, John C. Stennis Space Center, Stennis Space Center, MI 39529, U.S.A.

${ }_{5}^{4}$ Department of Geology, Florida Atlantic University, Boca Raton, FL 33431, U.S.A.

${ }_{6}^{5}$ Department of Geology, University of Leicester, United Kingdom.

${ }^{6}$ Geophysical Institute, Faculty of Science, University of Tokyo, Japan.

${ }^{7}$ Department of Geology, Stanford University, Stanford, CA 94305 , U.S.A.

${ }^{8}$ Institute of Geological Sciences, College of General Education, Osaka University, Toyonaka, Osaka 5560, Japan.

${ }^{9}$ Geologisches Institut, Universităt Koln, Federal Republic of Germany.

${ }^{10}$ Department of Geology, Northern Illinois University, DeKalb, IL 60115, U.S.A. U.S.A.

"Department of Oceanography, Florida State University, Tallahassee, FL 32306,

${ }^{12}$ Department of Geology and Geophysics, University of Utah, Salt Lake City, UT 84112 , U.S.A.

${ }^{13}$ Scripps Institution of Oceanography, University of California, San Diego, La Jolla, CA 92093 , U.S.A.

${ }_{14}$ Institute di Geologia Marina, Consiglio Nazionale D'Recherche, Bologna, Italy.

15 Department of Geosciences, San Francisco State University, San Francisco, CA 94132, U.S.A.

${ }^{16}$ Institut Angewandte Geophysik, Universităt Munchen, Munchen, Federal Republic of Germany.

${ }^{17}$ Department of Earth Sciences, Faculty of General Education, Yamagata University, Yamagata, 990 Japan
}

phy in such an active tectonic region, which, during its geologic history (particularly during the Quaternary), had a sometimes tenuous connection with the North Pacific. Earlier studies of sediment cores from the Sea of Japan and of marine sediments outcropping in western Japan had failed to resolve a coherent magnetostratigraphy, most probably because of problems associated with heat flow, sediment reworking, and the apparent stagnation of bottom waters in the Sea of Japan related to sea-level lowerings to near sill depth during late Quaternary glacial stages. Similarly, tenuous connections between the Sea of Japan and the North Pacific may have compromised the utility of some previously well-established micropaleontologic datum levels, particularly within the Quaternary. Thus, we sought not to improve on the basic North Pacific stratigraphic framework but to determine if it is equally applicable to the Sea of Japan.

In general, upper Neogene sediment sequences recovered during ODP Legs 127 and 128 contained poorly to well-preserved siliceous microfossils. The recovery of calcareous microfossils ranged from absent to moderately abundant. At most sites, Miocene/Pliocene and Pliocene sediments above the opal-A/opal-CT boundary were very diatomaceous (commonly dominated by valves of Coscinodiscus marginatus) whereas in Quaternary sediments diatoms were less abundant, ranging from rare to common. Foraminifers and calcareous nannoplankton show the opposite trend, being more common in the Quaternary part of the section. Below the opal-A/opal-CT boundary, preservation was variable, with sporadic pockets of dolomite or sand containing significant microfossil remains.

At most sites of both Legs 127 and 128 diatoms were more abundant in upper Pliocene sediments than in the Quaternary. The cyclic nature of their occurrence in both the Pliocene and Quaternary is noted by Koizumi (this volume) and displayed quantitatively (as percent opal) by Dunbar et al. (this volume). The diatom zonation of Koizumi (1985) as modified by Akiba (1985; taxonomically) and Akiba and Yanagisawa (1985; biostratigraphically) was found to be the most useful for both legs. Interestingly, the northwest Pacific zonation of Akiba (1985) was found to be less useful because this zonation is based, in part, on age-diagnostic species that are more common to the lower latitude Pacific. These include such stratigraphic markers as Rhizosolenia praebergonii, Nitzschia jouseae, and Thalassiosira miocenica. Their absence from, or sporadic occurrence in, Sea of Japan sediments likely reflects the frequent closure or restriction of the Tsushima Strait, particularly during the Pliocene and 
Pleistocene. This observation is also supported by data based upon radiolarians (Alexandrovich, this volume).

Similarly, higher latitude, stratigraphically useful, diatoms did not always penetrate into the southern part of the Sea of Japan, thus compromising their utility as stratigraphic markers in the Leg 128 sediments. This is particularly true for sediments older than late Pliocene. Indeed, it seems that such markers were not present or were diachronous in their first appearance between the northern part of the Sea of Japan (Leg 127) and the southern part (Leg 128). Further, such factors as the degree of diatom dissolution and the extreme abundance of the diatom Coscinodiscus marginatus made it difficult to locate, even with marginal accuracy, levels of diatom first or last appearance. The occurrence of $C$. marginatus ooze in the Leg 128 sediments was addressed by Burckle et al. (this volume), who proposed that it was a lag deposit, a product of silica dissolution. These results need additional verification and debate, however, because by extension such a conclusion casts doubt on the utility of diatoms as paleoceanographic indicators in other parts of the world. White and Alexandrovich (this volume), for example, suggested that the transition from silica-rich (i.e., C. marginatus) to silica-poor conditions in the late Pliocene resulted from the cessation of deep water exchange between the Sea of Japan and the Pacific.

Although radiolarians recovered from the Leg 128 sites were moderately well preserved, abundances were generally so low that it was difficult to find many of the useful stratigraphic markers recorded from the northwest Pacific. This was especially true for sediments of late Neogene age. According to Ling (chapter 13, this volume) during the late Neogene a warm-water assemblage similar to that of the northwest Pacific was replaced by unique post-middle Miocene faunas whereas the modern assemblage probably did not originate until the Quaternary. Fortunately, a radiolarian assemblage correlative to the middle Miocene Cyrtocapsella tetrapera Zone was identified in Hole 799B.

For reasons given in the preceding, radiolarian zonations previously set up for sediments from the Sea of Japan and the adjacent coast of Japan (Nakaseko and Sugano, 1973; Tamaki, Pisciotto, Allan, et al., 1990) were not applicable for zoning the sediments from Leg 127 or Leg 128. Additionally, poor preservation in Pliocene and Quaternary sediments made it difficult to determine exact stratigraphic positions of zonal boundaries. Further, except for the late Quaternary, most of the radiolarian datum levels identified in the samples from Legs 127 and 128 have not been assigned ages in studies of northwest Pacific sediments. For that reason, radiolarian stratigraphy was not used extensively to refine age models for the Leg 127 and 128 sites. However, the sequence of first and last appearances can be integrated with those of diatoms that, in the northwest Pacific, have been tied to other stratigraphic datums (i.e., magnetostratigraphy and oxygen isotopes). Although a silicoflagellate and ebridian zonation was not utilized for the Leg 127 sediments, Ling (chapter 14, this volume) found that it could be applied to the Leg 128 sediments. Indeed, in some holes it appeared to be more useful than the radiolarian stratigraphy. This latter comment may be a reflection of the fact that the persistence of shallow sills during at least part of the Neogene has restricted the influx of deeper dwelling radiolarians in the Sea of Japan (Alexandrovich, this volume).

In spite of the fact that they did not occur continuously, calcareous nannofossils, along with the foraminifers, were most useful in determining the age at the base of the section for either Leg 127 or Leg 128; the occurrence of the Helicosphaera ampliaperta Zone (15.718.4 Ma; Rahman, this volume) in Hole 797B gives a minimum age for the Yamato Basin and permits us to place time constraints on the opening of the Sea of Japan and the rotation of southwest Japan. The presence of this taxon, as well as other warm-water calcareous nannofossils (e.g., Sphenolithus), during the late early Miocene and the early middle Miocene likely reflects more open-ocean conditions for the Sea of Japan during this time. Within the limits dictated by microfossil preservation, sample spacing, and core recovery, it ap- pears that calcareous nannofossil datum levels for the sediments from Legs 127 and 128 are largely correlative with like datum levels in the northwest Pacific. Of particular importance from the study of Rahman (this volume) is the fact that the presence of well-dated calcareous nannofossil zones imposes serious limits on the timing of formation of the Sea of Japan and the rotation of southwest Japan. This, in turn, calls into question one of the models explaining the mechanics and timing of the opening of the Sea of Japan (Otofuji, Hayashida, and Torii, 1985; Otofuji, Matsuda, and Nohda, 1985) and calls for further review of other mechanisms and their associated timetables.

The utility of calcareous nannofossil datum levels at the Leg 128 sites is largely restricted to the Quaternary, and even then, there are differences between Sites 798 and 799. This is believed to be due to a number of factors, chiefly fluctuations in the depth to the carbonate compensation depth (CCD) and changes in the position of the frontal boundary between the warm-water Tsushima Current (entering the Sea of Japan from the south) and southward-flowing cold water (Muza, this volume). Depending upon the strength of the Tsushima Current, this frontal boundary probably fluctuated longitudinally at glacial/interglacial time scales. Following this line of reasoning, Muza (this volume) recognized six major intervals when the frontal boundary may have been to the north of Site 798 (i.e., interglacials) separated by five major intervals when the frontal boundary was probably to the south of this site (i.e., glacials). The fact that these intervals do not always approximate known glacial/interglacial boundaries may be a function of an inadequate age/depth model, and a greatly improved age/depth model may lead to a better understanding of this phenomenon, at least for the late Pleistocene. Although it is premature even to speculate about the timing of these changes, the ages of these events correlate closely to the ages of the Heinrich events in the North Atlantic (Broecker et al., in press). The mechanism governing such events in the Sea of Japan, however, would certainly be different.

As with the calcareous nannoplankton, planktonic foraminifers are most common in upper Pliocene and Pleistocene sediments for both Legs 127 and 128 (Brunner, this volume; Kheradyar, this volume). In the Pleistocene assemblages, coiling direction (CD) changes in Neogloboquadrina pachyderma, which is a reliable indicator of sea-surface temperature change in mid-latitude regions (Ericson, 1959; Bandy, 1959, 1960), were successfully used for some age and environmental interpretations. A major shift from dominantly dextral to dominantly sinistral populations is recorded in Core 128-798A$13 \mathrm{H}$ (Kheradyar, this volume). This shift is equivalent to the CD 10/11 boundary of Lagoe and Thompson (1988) representing the onset of mid-latitude glaciation at 1.2 Ma (Kent et al., 1971). The CD shifts of $N$. pachyderma in Brunhes-age sediments represent fluctuations in sea-surface temperature that correlate well with climatic fluctuations in the Northern Hemisphere predicted from oxygen isotope analyses (Imbrie et al., 1984; Prell et al., 1986; Kheradyar, this volume).

For the Leg 127 sites, it was also possible to zone, in part, the basal part of the sedimentary sequence (Brunner, this volume). The lower part of Hole 797B, for example, contains Catapsydrax parvulus, which ranges from about 17.6 to $10.2 \mathrm{Ma}$, and Globorotalia praescitula, which ranges from 15.0 to $14.0 \mathrm{Ma}$. This age call is consistent with that of Rahman (this volume), who based his analysis upon calcareous nannoplankton. Further, the interval containing these taxa is dominated by warm-water species (primarily Globoquadrina venezuelana) suggesting that the late early to early middle Miocene of the Sea of Japan was warmer than any interval higher in the sequence.

Benthic foraminifers were present in the sediments from all holes but abundances were generally low and occurrences sporadic. Nevertheless, the Neogene sequences could be assigned to the zonation of Matsunaga (1963; see Brunner, this volume). Benthic foraminifers provide important insight into the history of the Japan and Yamato basins (Brunner, this volume; Kato, this volume). The assessment of paleodepth using benthic foraminifers suggests that both the Japan 
and Yamato basins had subsided to lower middle bathyal depths $(1500-2500 \mathrm{~m})$ by the time the first foraminifer-bearing sediments (late early Miocene) were deposited above igneous basement at the sites where basement was drilled. Deep waters of the nascent and mature backarc basin were poorly oxygenated throughout most of the Miocene sequences; however, oxygenation improved in the latest Miocene and continued through the Pliocene. Quaternary assemblages suggest a depth shallower than the actual water depths from which they were recovered. This assemblage was introduced into the Sea of Japan in the earliest Quaternary and persists to the present.

Pollen analysis is not especially useful for datum level stratigraphy in the Sea of Japan. However, these data can be used to validate age calls from microfossil datum levels and to support the paleoenvironmental conclusions drawn from marine microfossil analysis. For example, Heusser (this volume) noted a unique, geologically brief, warm event at about $4 \mathrm{Ma}$ in the Leg 127 samples. Such an event has also been noted at this time in Southern Ocean sediments (Ciesielski and Weaver, 1974; Froelich et al., 1991) and in sea-level history (Haq et al., 1988; Dowsett and Cronin, 1990). In addition to being a unique stratigraphic marker this warm event may be used as the "golden spike" to tie together early Pliocene continental and marine records. The older part of the record is also amenable to pollen analysis. Yamanoi (this volume; see also Yamanoi, 1989) noted that his pollen zones NP-1 through NP-4 are present in the Miocene section of the Leg 127 sites. The NP-1/NP-2 boundary occurs at about $550 \mathrm{~m}$ below seafloor (mbsf) in Hole 797C at an age (17-18.5 Ma) that is consistent with that estimated from the calcareous nannoplankton (Rahman, this volume).

We also note what are still considered "nonclassical" methods of chronology: that is, oxygen isotope stratigraphy, percent opal stratigraphy, and well logging. The first two analyses are presented by Dunbar et al. (this volume). Although higher resolution data are required to recover fully the late Quaternary oxygen isotope curve for the Sea of Japan, if one integrates these data with microfossil datum levels and the $N$. pachyderma coiling change curve, it becomes apparent that oxygen isotope stages 2-12 are present in Hole 798B (Dunbar et al., this volume; Kheradyar, this volume; Burckle, this volume; Muza, this volume). Variations in well $\log$ data were found to reflect periodic variations in biogenic opal and terrigenous input and, further, the pattern closely follows the Pliocene-Pleistocene $\delta^{18} \mathrm{O}$ record. Spectral analysis of the log data covering the late Pliocene and early Quaternary shows that much of the variance is concentrated at the 41-k.y. obliquity band. Whereas the increased terrigenous fraction probably represents glacial stage input of eolian dust from China, higher percent biogenic opal represents increases in interglacial surface-water productivity and the access of Pacific surface water into the Sea of Japan via the Tsushima Strait (DeMenocal et al., this volume).

Finally, we note the presence of dark/light sediment rhythms (massive to finely laminated) in upper Miocene and upper Pliocene to Quaternary sediments of the Sea of Japan (Föllmi et al., this volume). The presence of such unique sedimentation events suggests that it may be possible, at least in some parts of the section, to resolve time on century or decade time scales or less. For example, in Samples 128-798B-10H-4, 111-116 cm, 128-798B-10H-4, 144 $149 \mathrm{~cm}$, and 128-798B-10H-7, 131-136 cm, we measured and determined average thicknesses for 20 fine laminations, with the laminae generally ranging between 0.050 and $0.0526 \mathrm{~cm}$. If one assumes that these are seasonal laminae and that each couplet represents one year, then the resulting sedimentation rate (approximately $100 \mathrm{~cm} / \mathrm{k} . \mathrm{y}$.) is not inconsistent with that expected for marginal seas. Using this argument, an interval of laminated sediments in Core 128-798B-10H-7 would represent something on the order of 600 to $1000 \mathrm{yr}$. It is apparent that further investigation of these dark/light rhythms (in conjunction with other nonclassical approaches) will provide us with a high-resolution chronostratigraphic record of the late Pliocene-Pleistocene, a record that will greatly exceed the resolution of the biostratigraphic method.

\section{Site 794}

Site $794\left(40^{\circ} 11.41^{\prime} \mathrm{N}, 138^{\circ} 13.86^{\prime} \mathrm{E}\right)$ is located along the eastern margin of the Sea of Japan approximately $175 \mathrm{~km}$ from the Oga Peninsula, northern Honshu (Tamaki, Pisciotto, Allan, et al., 1990). The water depth is $2811 \mathrm{~m}$, and the site is situated on a gently north-dipping slope that makes up the northeastern margin of the Yamato Basin. The isolation of Site 794 from two north-trending deep-sea channels means that at present it receives little coarse sediment. This site was chosen to determine the nature and age of basement, to measure the direction of the present stress field, and to characterize the sedimentation, subsidence, and paleoceanographic history of the area. Three holes were drilled at Site 794; of these, Hole 794A has the most complete recovery, with $302.16 \mathrm{~m}$ of sediment retrieved.

Although the sediment was not always stable to alternating field demagnetization, a nearly continuous magnetic reversal record extending from near the base of the Pliocene to the Quaternary was obtained for Site 794. Shore-based measurements confirmed the shipboard results but, as a result of weakly magnetized samples, it was not possible to resolve the reversal record below about $150 \mathrm{mbsf}$ (near the Miocene/Pliocene boundary). Within the late Neogene time interval, interpretation of the paleomagnetic record is fairly straightforward, particularly when done in conjunction with the biostratigraphy. The results are presented by Hamano et al. (chapter 62, this volume) and are summarized in Table 1 . In spite of the fact that the record is essentially clear, there are some ambiguities. For example, the Brunhes/Matuyama boundary is marked by an interval of $2 \mathrm{~m}$ of mixed polarity before a permanent change occurs at $27.15 \mathrm{mbsf}$. It is not clear if this is the result of geomagnetic field variation associated with a reversal or if changes in depositional setting are responsible. The latter process is more likely because the sedimentation rate at this site seems too low to capture any detailed record of the field reversal.

Relative ages based upon micropaleontology are dictated largely by diatoms (Koizumi, this volume) with contributions from radiolarians (Alexandrovich, this volume) and coccoliths (Rahman, this volume). All of the late Neogene diatom zones of Koizumi and Tanimura (1986) are recorded back to the Thalassionema schraderii Zone, which occurs in the middle of the late Miocene. Four radiolarian datum levels are recognized in the Quaternary sediments from Hole 794A. The first occurrence of Lychnocanium cf. L. grande is between 5.10 and 6.55 mbsf in upper Pleistocene sediments. The last occurrence of Clathrocyclas cabrilloensis is found just below this datum at 24.4 to $25.8 \mathrm{mbsf}$, near the Brunhes/Matuyama magnetic reversal boundary. Alexandrovich (this volume) noted that, in spite of taxonomic complications with this species, its last occurrence seems rather robust and the datum level can be correlated with confidence to holes at other Leg 127 sites. Similar comments may not be in order for the next oldest radiolarian datum level (last occurrence of Sphaeropyle robusta), which occurs between 33.89 and 35.30 mbsf at an estimated age of 0.977 to $1.024 \mathrm{Ma}$. Alexandrovich (this volume) pointed out that because of low abundances in Pleistocene sediments, this datum level may not be reliable.

The Pliocene/Pleistocene boundary at this site is placed at approximately 55 mbsf using both diatom and calcareous nannofossil markers (Koizumi, this volume; Rahman, this volume). The calcareous nannofossils are generally not represented in the late Miocene and Pliocene but the diatoms can be used to identify the Miocene/Pliocene boundary at approximately $180 \mathrm{mbsf}$. The identification is approximate because the boundary does not occur at a zonal boundary but was put just above the base of the Thalassiosira oestrupii (diatom) Zone. The opal-A/opal-CT boundary occurs at approximately 293 mbsf.

The primary objective of Leg 128 at Site 794 was to reenter Hole 794D in order to penetrate and sample acoustic basement; hence, no effort was made to recover magnetostratigraphic information. Both radiolarians and diatoms were recovered from a silty clay (Sample 128-794D-10R-1, 26-30 cm); unfortunately the radiolarians were 
Table 1. Summary of biostratigraphic and magnetostratigraphic datum levels for Leg $127 / 128$ sites.

\begin{tabular}{|c|c|c|c|c|c|c|c|}
\hline \multirow[b]{2}{*}{ Event } & \multirow{2}{*}{$\begin{array}{l}\text { Age } \\
(\mathrm{Ma})\end{array}$} & \multicolumn{6}{|c|}{ Depth (mbsf) } \\
\hline & & 794 & 795 & 796 & 797 & 798 & 799 \\
\hline FO E. huxleyi $(\mathrm{CN})$ & & & 21.1 & 16.1 & & 10.3 & \\
\hline FO $L$. sp. cf. grande (R) & & 5.8 & 23.6 & 7.9 & 25.5 & & \\
\hline LO R. curvirostris (D) & & 20.6 & 23.5 & 17.4 & 20.1 & 40.8 & 33.3 \\
\hline LO P. lacunosa $(\mathrm{CN})$ & & 21.1 & & 19.4 & 38.7 & & \\
\hline Brunhes/Matuyama (M) & 0.73 & 24.6 & 35.0 & & 38.3 & 79.5 & 90.0 \\
\hline LO C. cabrilloensis $(\mathrm{R})$ & & 25.1 & 42.6 & 46.0 & 39.2 & & \\
\hline LO D. subarctios $(\mathrm{S})$ & & & & & & 70.1 & 87.5 \\
\hline LO A. oculatus (D) & & 30.5 & 45.9 & 48.6 & & 94.1 & \\
\hline Top Jaramillo (M) & 0.90 & 31.1 & 46.0 & & $49.3 ?$ & 90.0 & 94.0 \\
\hline Base Jaramillo (M) & 0.98 & 34.1 & 48.6 & & $51.3 ?$ & 99.5 & 96.0 \\
\hline LO $S$. robusta $(\mathrm{R})$ & & 34.6 & 110.3 & 83.2 & 48.7 & & \\
\hline N. pachyderma dex. to $\sin (\mathrm{F})$ & & & & & & 92.0 & \\
\hline FO G. oceanica $(\mathrm{CN})$ & & & & & 58.2 & 147.6 & 105.2 \\
\hline Top Olduvai (M) & 1.66 & 54.6 & 87.0 & & 78.6 & 190.0 & 123.5 \\
\hline LO A. rectangulare $(\mathrm{E})$ & & & & & & 191.0 & 130.0 \\
\hline Base Olduvai (M) & 1.88 & 58.8 & 97.2 & & 84.6 & 212.0 & 131.5 \\
\hline LO N. koizumii (D) & & 59.0 & 109.0 & 55.2 & & 220.0 & \\
\hline FO D. aquilonius (R) & & & & & 160.6 & 162.2 & \\
\hline$L O L$ aff. $T$. redondoensis ( $R$ ) & & 68.5 & 157.2 & & 124.7 & & \\
\hline LO E. antiqua antiqua (E) & & & & & & 280.0 & 150.0 \\
\hline LO D. jimlingii (S) & & & & & & 290.0 & \\
\hline Matuyama/Gauss (M) & 2.47 & 75.4 & $137.9 ?$ & & $113.4 ?$ & 295.0 & 155.0 \\
\hline LO T. japonica $(\mathrm{R})$ & & 77.6 & 109.1 & 73.4 & 105.7 & 422.3 & \\
\hline FO T. davisiana $(\mathrm{R})$ & & 78.1 & 1479.7 & 83.2 & 110.0 & & \\
\hline LO N. kamtschatica (D) & & 78.0 & 147.0 & 83.2 & & 315.3 & 198.6 \\
\hline LO D. pseudofibula (S) & & & & & & 325.0 & \\
\hline FO N. koizumii (D) & & 87.5 & 225.2 & 122.0 & & & \\
\hline Top Kaena (M) & 2.92 & 89.8 & & & 126.0 & 320.0 & 187.0 \\
\hline Base Kaena (M) & 2.99 & 92.3 & & & 133.8 & 330.0 & \\
\hline Top Mammoth (M) & 3.08 & 95.5 & & & 143.6 & 410.0 & \\
\hline FO S. langii (R) & & 97.1 & 176.8 & 107.5 & 153.2 & & \\
\hline LO $S$. aff. S. aquilonarium (R) & & 97.1 & 147.1 & 83.2 & 153.2 & & \\
\hline LO B. bramlettii $(\mathrm{R})$ & & 97.1 & & & & & \\
\hline Base Mammoth (M) & 3.18 & 98.8 & & & 150.8 & 420.0 & 195.0 \\
\hline Gauss/Gilbert (M) & 3.40 & 108.2 & $239.0 ?$ & & 167.8 & & 215.0 \\
\hline LO $S$. peregrina $(\mathrm{R})$ & & 116.1 & & & 171.2 & & \\
\hline Top Cochiti $(\mathrm{M})$ & 3.88 & 125.1 & & & & & \\
\hline FO T. oestrupii (D) & & 125.5 & 189.5 & & & & \\
\hline LO R. califormica (D) & & 125.5 & & & & & \\
\hline Base Cochiti (M) & 3.97 & 126.7 & & & & & \\
\hline Top Nunivak (M) & 4.10 & 133.8 & & & & & \\
\hline Base Nunivak (M) & 4.24 & 135.9 & & & & & \\
\hline Top Sidufjiall (M) & 4.40 & 139.9 & & & & & \\
\hline Base Sidufjiall (M) & 4.47 & 140.4 & & & & & \\
\hline Top Thvera (M) & 4.57 & 143.8 & & & & & \\
\hline FO $L$. aff. $T$. redondoensis (R) & & 144.6 & 322.4 & & 209.5 & & \\
\hline Base Thvera $(\mathrm{M})$ & 4.77 & 148.5 & & & & & \\
\hline LO S. japonica (R) & & 168.8 & 361.1 & & 190.4 & & \\
\hline FO T, japonica (R) & & 192.7 & 332.1 & & 238.6 & & \\
\hline LO L nipponicum $(\mathrm{R})$ & & 192.7 & 389.6 & & 228.9 & & \\
\hline LO S. delmontensis (R) & & 202.4 & & & & & \\
\hline FO D. kamtschatica (D) & & 221.7 & 399.2 & 257.5 & & & \\
\hline LO T. anthopora (R) & & 241.1 & 437.6 & & & & \\
\hline LO T. mammilaris $(\mathrm{R})$ & & 250.9 & 437.6 & & & & \\
\hline LO T. schraderii (D) & & 250.8 & & & & & \\
\hline LO L tochigiensis $(\mathrm{R})$ & & 257.1 & 437.6 & & & & \\
\hline LOS. wolfii (R) & & 260.6 & & & & & \\
\hline LO D. katayamae (D) & & 289.0 & & & & & \\
\hline LO D. dimorpha (D) & & & 447.4 & & & & \\
\hline FO D. katayamae (D) & & 298.4 & & & & & \\
\hline FO D. dimorpha (D) & & & 447.4 & & & & \\
\hline LO C. tetrapera (R) & & 343.1 & & & & & \\
\hline LO C. floridanus $(\mathrm{CN})$ & & 371.1 & & & & & \\
\hline LO S. heteromorphus $(\mathrm{CN})$ & & 405.6 & & & 388.4 & & \\
\hline FO C. macintyrei $(\mathrm{CN})$ & & & & & 448.5 & 167.07 & \\
\hline LO D. praedimorpha (D) & & & 529.2 & & & & \\
\hline FO D. praedimorpha (D) & & & 640.1 & & & & \\
\hline FO D. hustedtii (D) & & & 703.5 & & & & \\
\hline
\end{tabular}


recrystallized to such an extent that the surface and internal structures were destroyed and species, and even generic, identification was not possible. Rare diatoms (Thalassionema nitzschioides and Coscinodiscus curvatulus) in this interval suggest a Neogene age which, when integrated with data from Leg 127 (Tamaki, Pisciotto, Allan, et al., 1990), further suggests a date of early to middle Miocene near the base of the hole.

\section{Site 795}

Site $795\left(40^{\circ} 98.7^{\prime} \mathrm{N}, 138^{\circ} 96.7^{\prime} \mathrm{E}\right)$ is located in a bathymetric embayment in the northernmost Japan Basin at water depths of 3300 (Hole 795A) and $3310 \mathrm{~m}$ (Hole 795B). This site was chosen to determine the nature and age of basement, to measure the magnitude and direction of the present stress field, and to characterize the sedimentation, subsidence, and paleoceanographic history of the area. Of the two holes drilled, Hole $795 \mathrm{~A}$ has the most complete recovery, with $258.26 \mathrm{~m}$ of sediment retrieved, but Hole 795B has the deepest penetration ( $397 \mathrm{mbsf}$ ).

Holes from Site 795 are characterized by stable magnetizations and reliable reversal stratigraphy for the Quaternary but with mixed and somewhat ambiguous results for the Pliocene. The interval from 0 to 104.3 mbsf exhibits a stable magnetic record and includes the Brunhes/Matuyama reversal as well as both the Jaramillo and Olduvai Subchrons. Just below this level, the sediments are characterized by scattered directions to a depth of $138 \mathrm{mbsf}$. Stable normal polarity field directions are present from this level to a depth of 172 mbsf. Hamano et al. (chapter 62, this volume) suggested that this normal interval may be the Gauss Chron, a view that is supported by the last occurrence of the diatom Denticulopsis kamtschatica at 151.9 mbsf (Koizumi, this volume). As at Site 794, the Brunhes/Matuyama boundary is not sharp but is characterized by at least one reversal some $85 \mathrm{~cm}$ below the reversal. Also, as at Site 794, this event appears to be of secondary rather than primary origin.

According to Koizumi (this volume), no major hiatuses are recorded in the Site 795 holes back to the latest Miocene/early Pliocene, below which is the opal-A/opal-CT boundary. Based upon the magnetic reversal stratigraphy, the Pliocene/Pleistocene occurs at approximately $87 \mathrm{mbsf}$, whereas the Miocene/Pliocene boundary likely occurs below $300 \mathrm{mbsf}$. As noted previously, there is no useful magnetic polarity reversal record below the Gauss Chron. However, the diatom data are robust and suggest strongly that the Miocene/Pliocene boundary occurs near the opalA/opal-CT boundary.

\section{Site 796}

Site $796\left(42^{\circ} 189.4^{\prime} \mathrm{N}, 139^{\circ} 41.1^{\prime} \mathrm{E}\right)$ is located on the eastward-dipping slope of Okushiri Ridge on the eastern margin of the Sea of Japan (Tamaki, Pisciotto, Allan, et al., 1990). The slope is believed to have been formed by a westward-dipping thrust fault. Water depth ranges from 2570.6 (Hole 796A) to $2622.6 \mathrm{~m}$ (Hole 796B). This site was chosen to determine the age and uplift history of the ridge, to measure the direction of the present stress field, to determine the age and character of basement, and to characterize the sedimentation, subsidence, and paleoceanographic history of the area. Of the two holes drilled at Site 796, Hole 796A has the most complete recovery, with $155.25 \mathrm{~m}$ of sediment retrieved, but Hole $796 \mathrm{~B}$ penetrates to a greater depth. As noted in Tamaki, Pisciotto, Allan, et al. (1990) the sediment recovered from this site was disrupted extensively by gas explosions, compromising its magnetostratigraphy.

As at most Leg 127 and Leg 128 sites, a useful magnetic stratigraphy was recovered only for the Pliocene-Pleistocene interval. Because of the lack of magnetostratigraphic control, placement of the Pliocene/Pleistocene boundary could only be approximated. It is placed in the upper part of the Neodenticula koizumii (diatom) Zone at an approximate depth of $40 \mathrm{mbsf}$. This is in approximate agreement with evidence from radiolarians (Alexandrovich, this volume) and calcareous nannofossils (Rahman, this volume). The opal-A/opal-CT boundary occurs in the Neodenticula kamtschatica (diatom) Zone at about $223 \mathrm{mbsf}$. If one assumes that the distribution of calcareous nannofossils in the Sea of Japan is controlled solely by surface-water hydrography rather than by diagenetic processes then it is reasonable to argue that the base of Hole 796B is younger than 13.1 Ma (Rahman, this volume).

\section{Site 797}

Site $797\left(38^{\circ} 616^{\prime} \mathrm{N}, 134^{\circ} 536^{\prime} \mathrm{E}\right)$ is located in the southwestern Yamato Basin some $300 \mathrm{~km}$ from the western coast of Honshu. It is situated at the base of the slope that joins the Yamato Rise and the Kita-Oki Bank. Water depths are 2862.2 (Holes 797A and 797B) and $2864.6 \mathrm{~m}$ (Hole 797C). This site was chosen to determine the age and uplift history of the ridge, to measure the direction of the present stress field, to determine the age and character of basement, and to characterize the sedimentation, subsidence, and paleoceanographic history of the area.

Although some effort was devoted to recovering the magnetostratigraphy of the entire 495.7-m length from Hole 797B, a reliable reversal pattern was obtained only for the upper $170 \mathrm{~m}$ (late Pliocene to Quaternary). This includes the upper silty clay and clay of lithostratigraphic Unit I ( $0-119.9 \mathrm{mbsf})$ and part of the diatomaceous ooze and clay of Unit II (119.9-224 mbsf). All major chrons were identified down to the Gauss/Gilbert; however, scattered directions obscured the position of the Jaramillo Subchron to the extent that it could not be located accurately. Further, the level of the Gauss/Matuyama boundary was obscured by scattered directions, thus making the exact location of this boundary difficult to determine. The younger two subchrons of the Gilbert (Cochiti and Nunivak) are present below the Gauss/Gilbert boundary.

According to Koizumi (this volume) the section down to the opal-A/opal-Ct boundary is reasonably complete with all diatom zones identified from the late Quaternary to the early late Miocene. The Pliocene/Pleistocene boundary occurs at approximately $78 \mathrm{mbsf}$. There is no magnetic control to identify the Miocene/Pliocene boundary but it probably occurs at about 200 mbsf in the lower part of the Thalassiosira oestrupii (diatom) Zone. The Denticulopsis katayamae (diatom) Zone occurs at approximately $288 \mathrm{mbsf}$, just above the opal-A/opal-CT boundary at 292 mbsf. In addition, calcareous nannoplankton can be used to assign the interval between 385 and 450 mbsf to the middle Miocene Sphenolithus heteromorphus Zone and the interval from 450 to 493 mbsf to the Helicosphaera ampliaperta Zone. Of special significance is that Site 797 contains the apparently oldest nannofossil-bearing sediments for both Legs 127 and 128; the sample at approximately 535 mbsf falls between 15.7 and $18.4 \mathrm{Ma}$. The late early Miocene foraminifers Globorotalia praescitula and Catapsydrax parvulus occur at 495 and 515 mbsf, respectively. These data are consistent with the placement of pollen zonal boundaries NP-2/NP-3 (13 Ma) at about $410 \mathrm{mbsf}$ and NP-1/NP-2 (17-18.5 Ma) at about 550 mbsf (Yamanoi, this volume).

\section{Site 798}

Three holes were drilled at Site $798\left(37^{\circ} 3.832^{\prime} \mathrm{N}, 134^{\circ} 79.976^{\prime} \mathrm{E}\right)$, which is located on the Oki Ridge in the southeastern part of the Sea of Japan. The primary objective at this site was to obtain a Miocene to Holocene paleoceanographic reference section in pelagic and/or hemipelagic sediments that were deposited above the local CCD. Additionally, microbiologic samples were collected at Site 798 in order to quantify the role of bacteria in the diagenesis of marine sediments. The major objective was largely accomplished in that a thick middle Pliocene to Pleistocene section was identified with reasonably good recovery of biosiliceous and biocalcareous plankton. However, because of downcore diagenesis, it became increasingly difficult to date the sediments using micropaleontologic and magne- 
tostratigraphic methods. Owing to abrupt increases in gaseous hydrocarbons, drilling was stopped near what was believed to be the Miocene/Pliocene boundary.

The Brunhes/Matuyama Chron transition occurs at sub-bottom depths of 75.5, 79.5, and 80.5 m in Holes 798A, 798B, and 798C, respectively. The Jaramillo Subchron was clearly recorded in all three holes at depths of 86-95.5, 90-99.5, and 91-100.5 mbsf; however, because the reversal boundary coincides with the core boundary, the depth range at Hole $798 \mathrm{C}$ is considered somewhat ambiguous. Because the greatest penetration occurred at Hole 798B, the polarity sequence was continued in this hole. However, because of the difficulty in obtaining stable directions, tentative reversal boundaries were identified only to the Gauss/Gilbert Chron boundary. The Olduvai Subchron occurs between depths of 190 and 212 mbsf and the Matuyama/Gauss Chron boundary is at approximately $295 \mathrm{mbsf}$. More tentative is the placement of the Kaena and Mammoth Subchrons; the former probably occurs between 320 and 330 mbsf and the latter between 410 and 420 mbsf. Below this level, it is difficult to extract a meaningful magnetostratigraphic record. Further, the occurrence of the opal-A/opal-CT boundary at $455 \mathrm{mbsf}$ has reduced the integrity of both the magnetostratigraphic and biostratigraphic age picks considerably.

The diatom and silicoflagellate/ebridian zones (Burckle, this volume; Ling, chapter 14, this volume) appear complete for this site, at least back to the Miocene/Pliocene boundary. Because of low species diversity and the absence of generally recognized index forms it was not possible to zone the early Pleistocene or Pliocene using radiolarians. Similarly, because of preservation problems, calcareous nannofossil and planktonic foraminifer zonations were generally not applicable before the early Pleistocene. The Pliocene/Pleistocene boundary in Hole 798B occurs at about 190 mbsf and, in addition to the magnetostratigraphy, is identified by the last occurrence of the diatom Neodenticulopsis koizumii. There is some question about the age of the sediment just above the opal-A/opal-CT boundary at Site 798. Both the paleomagnetic and biostratigraphic data are somewhat tenuous just above the boundary. Radiolarian and silicoflagellate/ebridian preservation is not good at this level and diatoms are represented predominately by Coscinodiscus marginatus, thus making it difficult to identify zonal markers. Our best estimate, however, is that the sediments above the opal-A/opal-CT boundary are Pliocene in age.

\section{Site 799}

Site $799\left(39^{\circ} 22.046^{\prime} \mathrm{N}, 133^{\circ} 86.685^{\prime} \mathrm{E}\right)$ is located in the KitaYamato Trough between the Yamato Bank to the east and the KitaYamato Bank to the west. Objectives included a focus on the paleoceanographic history of the Yamato Rise area as well as the Sea of Japan as a whole. However, the major emphasis at this site was to determine the depositional and tectonic history of this trough, which was thought to be representative of sedimented failed rifts and ideal for the occurrence of massive sulfide deposits of the type found in the Kuroko region of Japan. Nearly 1100 m of lower Miocene through Holocene sediment was recovered before increases in hydrocarbon gases forced a halt to drilling about $120 \mathrm{~m}$ above acoustic basement. The opal-A/opal-CT boundary occurs at about $435 \mathrm{mbsf}$ at this site just below what is believed to be the Miocene/Pliocene boundary. Largely biosiliceous sediments occur between the opal-A/opal-CT transition and the Pliocene/Pleistocene boundary, above which the sediments generally do not have high levels of a biocalcareous or biosiliceous component.

All major geomagnetic polarity transitions were recognized for the Pliocene and Pleistocene, although there was some question about the latest Miocene transition. The validity of subchrons within the Gilbert will need to be confirmed by additional work. Major slump features as well as drilling disturbances and weak magnetization in
Quaternary sediments made it difficult to determine polarity transitions. Similarly, the determination of polarity directions below the opal-A/opal-CT boundary was possible only in some layers of porcellanite, dolomites, and coarse-grained sandstones. Polarity determination was further compromised by overprinting within the siliceous clays.

Despite these difficulties, major polarity transitions were measurable, particularly for the late Pliocene and Quaternary. The Brunhes/Matuyama Chron boundary occurs at $89.95 \mathrm{mbsf}$ and the upper and lower boundaries of the Jaramillo Subchron occur at 93.25 and 96.15 mbsf, respectively. The Olduvai Subchron is also present (occurring between 123.45 and $133.05 \mathrm{mbsf}$ ), as is the Matuyama/Gauss Chron boundary at $173.55 \mathrm{mbsf}$. Only the Kaena Subchron was observed in the Gauss, at a depth of 196.42 mbsf. Below the Gauss/Gilbert boundary, the weak magnetization of the sediments makes many of the polarity reversals questionable. Nevertheless, some of the subchrons of the Gilbert may be recognized (e.g., probable Nunivak Subchron at $362.2 \mathrm{mbsf}$ ).

As at Site 798, the Pliocene-Pleistocene section at this site seems reasonably complete with all diatoms and silicoflagellate/ebridian zones present. Radiolarian and calcareous nannofossil zones can be identified in the Quaternary but, largely because of dissolution, are not recognized in the Pliocene. The Pliocene/Pleistocene boundary is present at approximately $124 \mathrm{mbsf}$ in Hole 798A. Also as at Site 798, there is some question about the placement of the Miocene/Pliocene boundary in the Site 799 sediments. Magnetic reversal data are questionable below the Gauss Chron and diatom zonal markers may be masked by the great abundance of $C$. marginatus. However, the Miocene/Pliocene boundary may have been crossed because the oldest diatom zone in the Pliocene (Thalassiosira oestrupii Zone) was encountered just above the opal-A/opal-CT boundary. A tentative middle/late Miocene boundary is placed at approximately $520 \mathrm{mbsf}$ and the early/middle Miocene boundary is placed (also tentatively) at about 980 mbsf. There are scattered data (based on diatoms, radiolarians, calcareous nannoplankton, and foraminifers) indicating that the interval between 520 and 980 mbsf belongs to the middle Miocene.

\section{SUMMARY}

Table 1 lists the depths of some of the biostratigraphic and magnetostratigraphic datums from the sites of Legs 127 and 128, and Figure 1 summarizes diatom and radiolarian zonal data for these legs. Additionally, it summarizes calcareous nannofossil data from the middle Miocene of the Leg 127 sites. Figure 2 summarizes the Leg 128 data for the silicoflagellate/ebridian zonal scheme, whereas Figure 3 graphs sedimentation rates (and the depth to the opal-A/opal-CT boundary) for sites from both legs. With the exception of the Leg 127 radiolarian zones, which were modified from previously existing zonations (Tamaki, Pisciotto, Allan, et al., 1990), no new zonal schemes were proposed for other microfossil groups found in sediments from either Leg 127 or 128 . In each case, zonal schemes used in the northwest Pacific as well as elsewhere were applicable to the Sea of Japan. This conclusion should be considered tentative, however, because magnetostratigraphic constraints were generally not available below the upper part of the Gilbert Chron. However, the sequence of biostratigraphic events was similar to what is observed in the northwest Pacific.

The main summary points to be made here are as follows:

1. Site 794 was occupied at a water depth of $2811 \mathrm{~m}$. Sediment types (from youngest to oldest) include alternating, laminated lightand dark-colored silty clay, diatom ooze, diatomaceous clay, siliceous claystone, laminated claystone, and silty calcareous claystone. The deepest hole penetrated basalt (with interbedded tuff) beneath sediments of middle Miocene age. The opal-A/opal-CT boundary was penetrated at approximately $290 \mathrm{mbsf}$. Sedimentation rates ranged from 29 to $54 \mathrm{~m} / \mathrm{m}$.y. (with an average of $37 \mathrm{~m} / \mathrm{m}$.y.) with the lowest 


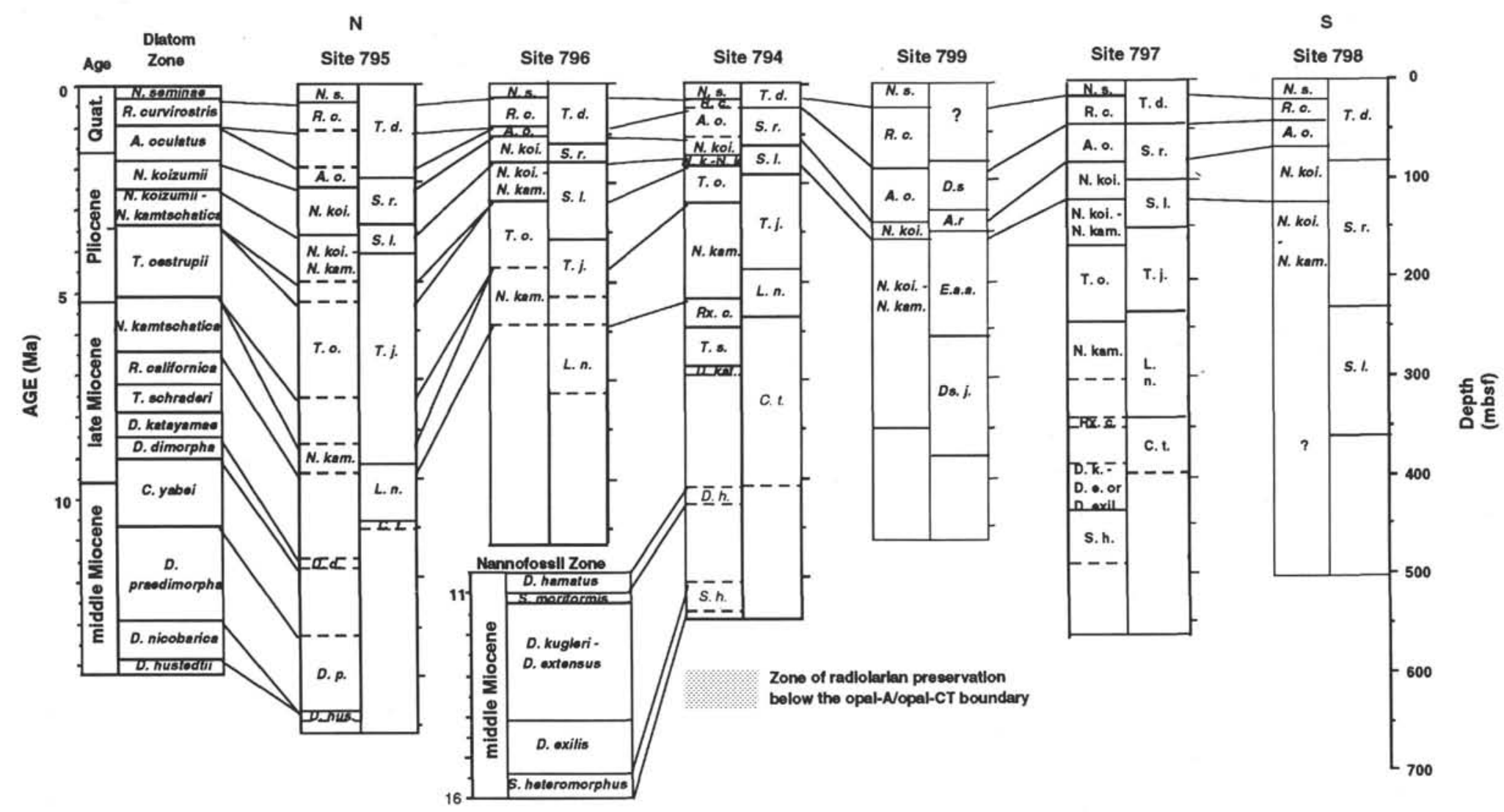

Figure 1. Summary of diatom, radiolarian, and silicoflagellate/ebridian zonal data for Legs 127 and 128. Please note the following for diatoms: $N . s .=N e o d e n t i c u l a ~ s e m i n a e, R . c .=$ Rhizosolenia curvirostris, $A . o_{.}=$Actinocyclus oculatus, $N$. koi. $=$ Neodenticula koizumii, $N$. koi. $-N$. kam. $=$ Neodenticula koizumii- $N$. kamtschatica,$T . o .=$ Thalassiosira oestrupii, $N$. kam. $=$ Neodenticula kamtschatica, $R x . c .=$ Rouxia californica, $T . s .=$ Thalassiosira schraderi, $D$. kat.$=$ Denticulopsis katayamae, D. $d .=$ Denticulopsis dimorpha, $D$. $p .=$ Denticulopsis praedimorpha , and $D$. hus. $=$ Denticulopsis hustedtii. For radiolarians (right-hand column at each site): $T . d .=$ Theocalyptra davisiana, $S . r .=S p h a e r o p y l e$ robusta, S. $l .=S p h a e r o p y l e$ langii, $T . j .=$ Thecosphaera japonica, $L_{n} n .=$ Lychnocanium nipponicum, and $C . t .=$ Cyrtocapsella tetrapora. For silicoflagellates/ebridians: Ds. $o .=$ Distephanus octangulatus, $D . s$. $=$ Dictyocha subarctius, A. $r=$ Ammodochium rectangulare, E. a. $a .=$ Ebriopsis antiqua antiqua , and Ds. $j .=$ Distephanus jimlingii. Nannofossil zones apply to Site 794 and are from Rahman (this volume). 


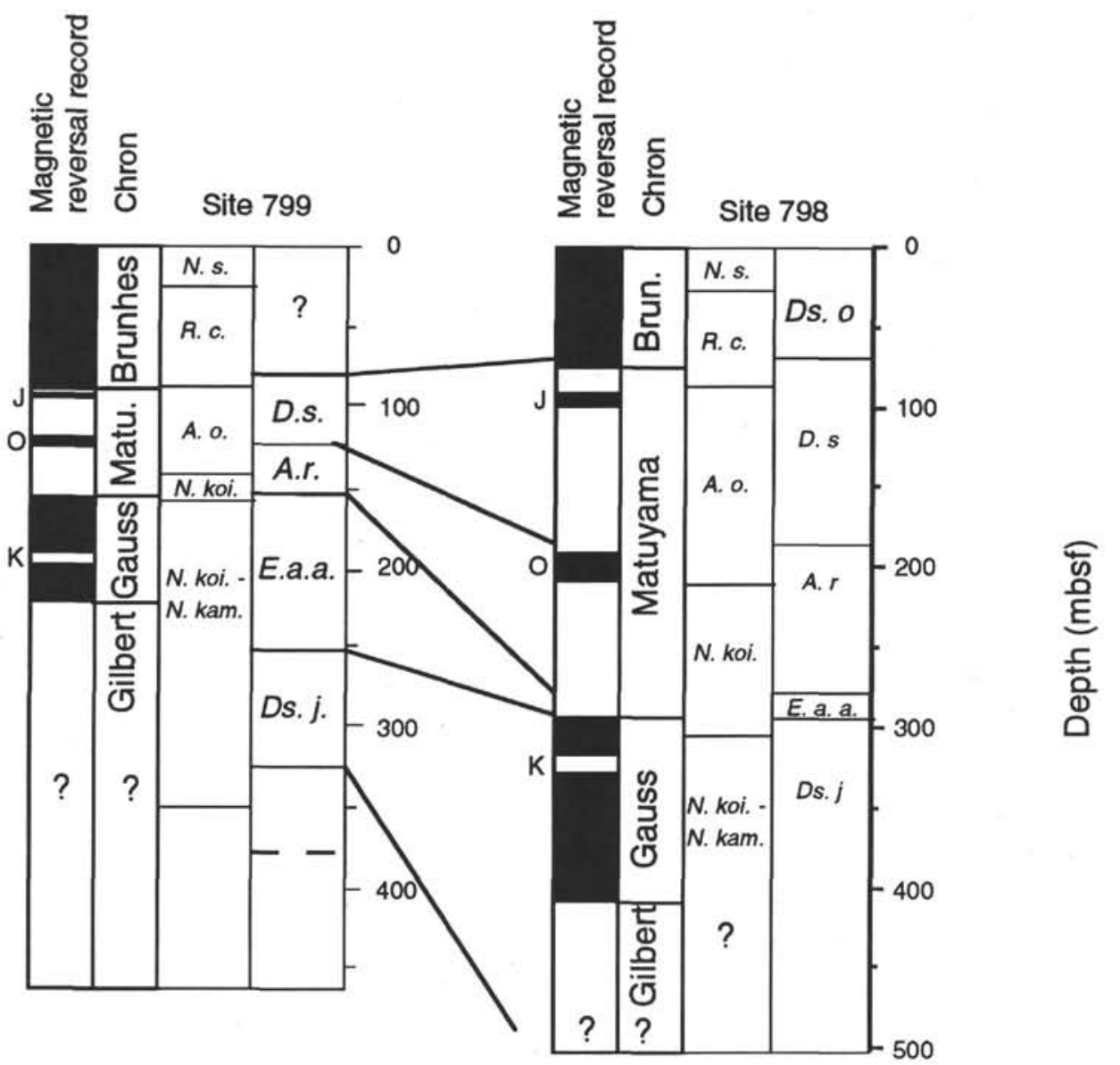

Figure 2. Summary of diatom, silicoflagellate, and ebridian zonal data for Leg 128 Sites 798 and 799. Please note the following for diatoms (left-hand column): $N . s .=$ Neodenticula seminae, $R . c .=$ Rhizosolenia curvirostris, A. o. = Actinocyclus oculatus, $N$. koi. $=$ Neodenticula koizumii, and $N . k o i .-N$. kam. $=$ Neodenticula koizumii- $N$. kamtschatica. For silicoflagellates and ebridians (right-hand column): Ds. o. = Distephanus octangulatus, $D . s .=$ Dictyocha subarctius, $A . r .=$ Ammodochium rectangulare, E. $a . a .=$ Ebriopsis antiqua antiqua, and Ds. j. = Distephanus jimlingii. Time scale of Berggren et al. (1985) is used.

rates in lower Pliocene sediments and the highest rates in the upper Miocene just above the opal-A/opal-CT boundary.

2. Site 795 is located in a bathymetric embayment in the northernmost Japan Basin at water depths of 3300 (Hole 795A) and $3310 \mathrm{~m}$ (Hole 795B). From youngest to oldest, the sediments include silty clay and claystone with interbedded diatom ooze, diatom ooze, silty clay, and siliceous claystone. The deepest layer (claystone) overlying basalt was dated as middle Miocene. The opal-A/opal-CT boundary was penetrated at approximately $325 \mathrm{mbsf}$. Sedimentation rates ranged from 29 to $77 \mathrm{~m} / \mathrm{m}$.y. (average of $53 \mathrm{~m} / \mathrm{m} . \mathrm{y}$.) with the highest rates in upper Pliocene and upper Miocene sediments and the lowest rates in middle Miocene sediments.

3. Site 796 is located on the eastward-dipping slope of Okushiri Ridge near the eastern margin of the Sea of Japan in water depths ranging from 2570.6 (Hole 796A) to $2622.6 \mathrm{~m}$ (Hole 796B). Sediment types (from youngest to oldest) include clay and silty clay, diatom ooze and diatom clay, and siliceous claystone, sandstone, and siltstone. The opal-A/opal-CT boundary occurs at approximately $224 \mathrm{mbsf}$, and the age of the deepest penetration is late Miocene. Sedimentation rates ranged from 9 to $74 \mathrm{~m} / \mathrm{m}$.y. with the highest rates in the Quaternary and near the base of the section. The lowest rates were recorded in the lower Quaternary, possibly indicating an unconformity.

4. Site 797 is located in the southwestern Yamato Basin some $300 \mathrm{~km}$ from the western coast of Honshu in water depths of 2862.2 (Holes 797A and 797B) and 2864.6 m (Hole 797C). From youngest to oldest the sediment types include silty clay and claystone, diatom ooze with minor claystone, and silty clay and claystone. Sediments of middle Miocene age overlie basalt. The opal-A/opal-CT boundary was encountered at 299 mbsf. Sedimentation rates ranged from 5 to $56 \mathrm{~m} / \mathrm{m}$.y. with the highest rates occurring in uppermost Miocene to Pleistocene sediments. The lowest rate is recorded for the upper Miocene.

5. Site 798 is located on the Oki Ridge in the southeastern part of the Sea of Japan in water depths of 903.1 (Hole 798A), 911.1 (Hole 798B), and $900.1 \mathrm{~m}$ (Hole 798C). The sediment types (from youngest to oldest) include silty and diatomaceous clay with well-defined interbeds of dark/light laminated sediments and diatomaceous clay grading downsection into a largely siliceous clay overlying a siliceous claystone. The basal age was difficult to determine because of sediment diagenesis but is believed to be late Miocene or earliest Pliocene. The opal-A/opal-CT boundary is at approximately $455 \mathrm{mbsf}$. Sedimentation rates ranged from 45 to $216 \mathrm{~m} / \mathrm{m}$.y. with an average rate of $121 \mathrm{~m} / \mathrm{m}$.y. The highest rates occurred in Pliocene sediments whereas rates close to the overall average are noted for the Quaternary.

6. Site 799 is located in the Kita-Yamato Trough between the Yamato Bank to the east and the Kita-Yamato Bank to the west in water depths of 2073 (Hole 799A), 2083.5 (Hole 799B), and $2071.7 \mathrm{~m}$ (Hole 799C). From youngest to oldest, the sediment types include diatomaceous clay and silty clay and diatomaceous ooze grading downsection to diatomaceous clay and overlying a predominately siliceous claystone. The oldest sediment penetrated was middle 


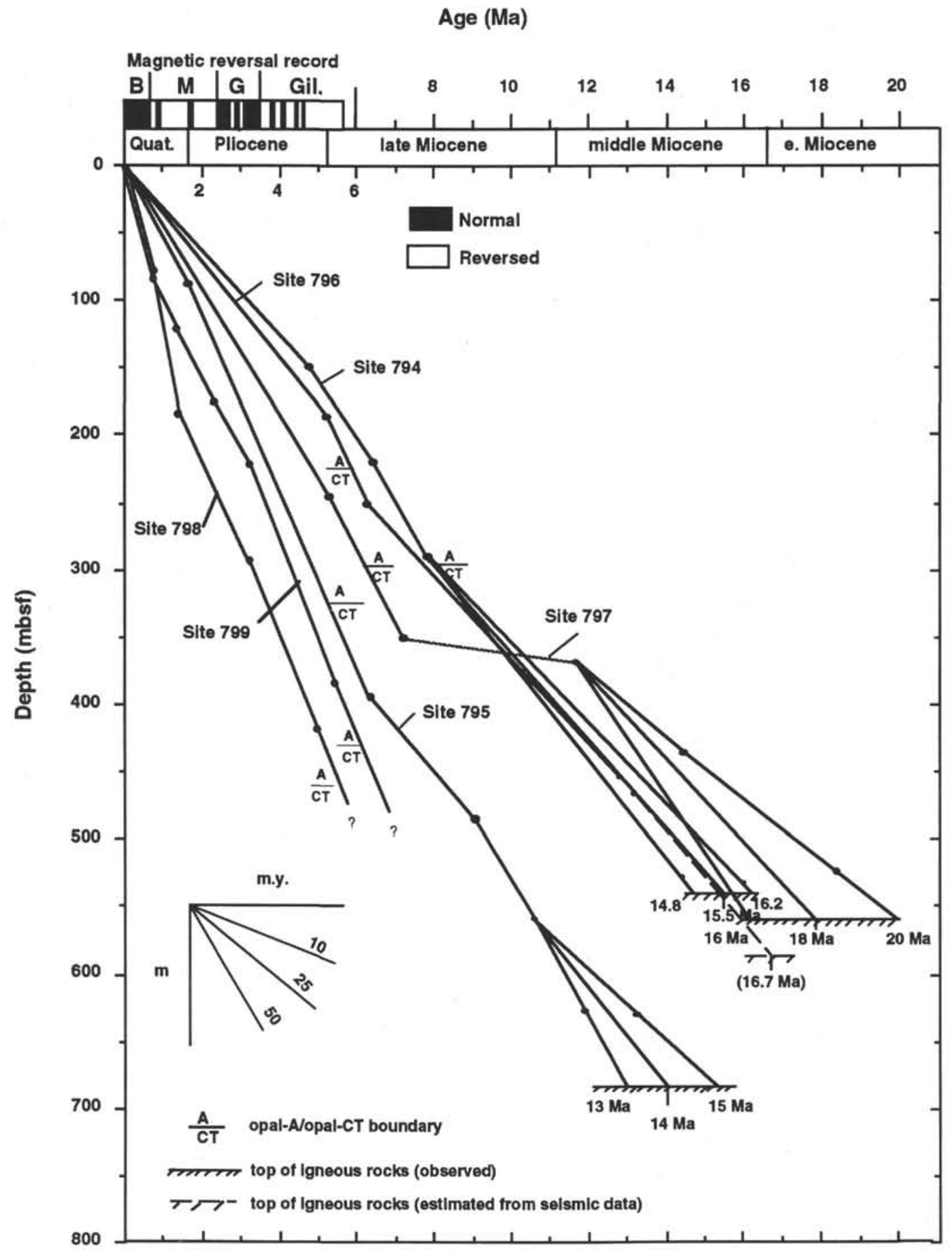

Figure 3. Sedimentation rates for recovery at Leg 127 and 128 holes. Where more than one sedimentation rate is indicated the age of the zonal marker or the basement age is still in question. For the paleomagnetic reversal record, $\mathrm{B}=\mathrm{Brunhes}, \mathrm{M}=$ Matuyama, $\mathrm{G}=$ Gauss, and Gil. $=$ Gilbert .

Miocene and possibly early Miocene. The opal-A/opal-CT transition occurs at 435 mbsf. Sedimentation rates ranged from as low as $15 \mathrm{~m} / \mathrm{m} . \mathrm{y}$. to more than $175 \mathrm{~m} / \mathrm{m} . \mathrm{y}$. with an average rate of approximately $70 \mathrm{~m} / \mathrm{m}$.y. Highest rates occurred in the upper Quaternary, with above average rates in the lower Quaternary whereas the Pliocene showed rates that were below or near the average.

Although one would expect higher sedimentation rates to occur in basins, the lowest rates are found in recovery from holes in the Yamato and Japan basins and on the east-facing slope of the Okushiri Ridge. The highest sedimentation rates are in the Kita-Yamato Trough (Site 799) and on the crest of the Oki Ridge (Site 798). In addition to pelagic and terrestrial sediments (largely of eolian and volcanic origin), for at least the late Pliocene and Quaternary, the Kita-Yamato Trough has received sediments sloughed off the adjacent Yamato and Kita-Yamato banks. This is reflected in the nature of the sediments found in the holes at Site 799. The pelagic sequence is interrupted by turbidites and reworked sediments. Site 798, on the other hand, is on 
a topographic high and, except for volcanic ash and eolian sediments, has received largely pelagic sediments. Higher sedimentation rates here can be attributed to the high surface-water productivity and the fact that the site is in relatively shallow water, well above the CCD. The lower sedimentation rates that are characteristic of sites occupied by Leg 127 appear to be a function of a number of factors, including topography, distance from terrestrial sources, greater depth combined with lower productivity of the overlying surface waters, and locations on the seaward side of the basins.

Within the constraints provided by the chronostratigraphy of the sediments recovered on Legs 127 and 128 two main questions may be addressed: (1) what is the time of formation and the early history of the Sea of Japan and (2) what was the late Pliocene and Quaternary climatic and oceanographic response to such physical events as changes in access of Pacific water to the Sea of Japan via the Tsushima Strait, sea-level lowering, and apparent glacial/interglacial changes in salinity and deepwater formation. The biostratigraphic and micropaleontologic data suggest that the Sea of Japan had already formed and was at bathyal depths by the late early Miocene (Brunner, this volume). Although the PlioceneQuaternary record from the Sea of Japan is impressive it will be some time before a comprehensive paleoceanographic and paleoclimatic history will be written. In the interim, efforts will focus on constructing a higher resolution age model for the Sea of Japan sites using oxygen isotopes, percent opal, $N$. pachyderma coiling direction changes, and statistical analysis of dark/light sediment rhythms (see, for example, DeMenocal et al., this volume; Dunbar et al., this volume; Föllmi et al., this volume; Kheradyar, this volume; Tada et al., this volume).

\section{ACKNOWLEDGMENTS}

Support was provided by USSAC grants (NSF). We acknowledge and appreciate discussion and input from our shipboard and shorebased colleagues. The senior author wishes to thank the Ocean Drilling Program for stocking the JOIDES Resolution with a supply of BRAN sufficient to last the entire cruise.

\section{REFERENCES}

Akiba, F., 1985. Middle Miocene to Quaternary diatom biostratigraphy in the Nankai trough and Japan Trench and modified lower Miocene through Quaternary diatom zones for middle-to-high latitudes of the North Pacific. In Kagami, H., Karig, D. E., Coulbourn, W. C., et al., Init. Repts. DSDP, 87: Washington (U.S. Govt. Printing Office), 393-482.

Akiba, F., and Yanagisawa, Y., 1985. Taxonomy, morphology and phylogeny of the Neogene diatom zonal marker species in the middle-to-high latitudes of the North Pacific. In Kagami, H., Karig, D. E., Coulbourn, W. C., et al., Init. Repts. DSDP, 87: Washington (U.S. Govt. Printing Office), 483-554.

Bandy, O. L., 1959. The geological significance of coiling ratios in the foraminifer Globigerina pachyderma (Ehrenberg). Geol. Soc. Am. Bull., 70:1708.

, 1960. The geological significance of coiling ratios in the foraminifer Globigerina pachyderma (Ehrenberg). J. Paleontol., 34:671-681.

Berggren, W. A., Kent, D. V., and Van Couvering, J. A., 1985. The Neogene: Part 2. Neogene geochronology and chronostratigraphy. In Snelling, N. J. (Ed.), The Chronology of the Geologic Record. Geol. Soc London Mem., 211-260.

Broecker, W., Bond, G., Klas, M., Clark, E., and McManus, J., in press. Origin of the northern Atlantic's Heinrich events. Clim. Dyn.
Ciesielski, P. F., and Weaver, F. M., 1974. Early Pliocene temperature changes in the Antarctic seas. Geology, 2:511-515.

Dowsett, H. J., and Cronin, T. M., 1990. High eustatic sea level during the middle Pliocene: evidence from the southeastern U.S. Atlantic coastal plain. Geology, 18:435-438.

Ericson, D. B., 1959. Coiling direction of Globigerina pachyderma as a climatic index. Science, 130:219-220.

Froelich, P. N., Malone,P. N., Hodell, D. A., Ciesielski, P. F., Warnke, D. A., Westall, F., Hailwood, E. A., Nobes, D. C., Fenner, J., Meinert, J., Mwenifumbo, C. J., and Muller, D. W., 1991. Biogenic opal and carbonate accumulation rates in the subantarctic South Atlantic: the late Neogene of Meteor Rise Site 704. In Ciesielski, P. F., Kristoffersen, Y., et al., Proc. $O D P$, Sci. Results, 114: College Station, TX (Ocean Drilling Program), 515-550.

Haq, B. U., Hardenbol, J., and Vail, P. R., 1988. Mesozoic and Cenozoic chronostratigraphy and cycles of sea-level change. In Wilgus, C. K., Hastings, B. S., Kendall, C.G.St.C., Posamentier, H. W., Ross, C. A., and Van Wagoner, J. C. (Eds.), Sea-Level Changes-An Integrated Approach. Spec. Publ.-Soc. Econ. Paleontol. Mineral., 42:71-108.

Imbrie, J., Hays, J. D., Martinson, D. G., McIntyre, A., Mix, A. C., Morley, J. J., Pisias, N. G., Prell, W. L., and Shackleton, N. J., 1984. The orbital theory of Pleistocene climate: support from a revised chronology of the marine $\delta^{18} \mathrm{O}$ record. In Berger, A., Imbrie, J., Hays, J., Kukla, G., and Saltzman, B. (Eds.), Milankovitch and Climate (Pt. 1): Dordrecht (D. Riedel), 269-305.

Kent, D., Opdyke, N. D., and Ewing, M., 1971. Climatic change in the North Pacific using ice-rafted detritus as a climatic indicator. Geol. Soc. Am. Bull., 82:2741-2754.

Koizumi, I., 1985. Diatom biochronology for late Cenozoic northwest Pacific. J. Geol. Soc. Jpn., 91:195-211.

Koizumi, I., and Tanimura, Y., 1986. Neogene diatom biostratigraphy of the middle latitude western North Pacific, Deep Sea Driling Project Leg 86. In Heath, G. R., Burckle, L. H., et al., Init. Repts. DSDP, 86: Washington (U.S. Govt. Printing Office), 269-300.

Lagoe, M. B., and Thompson, P. R., 1988. Chronostratigraphic significance of late Cenozoic planktonic foraminifera from the Ventura Basin, California: potential for improving tectonic and depositional interpretation. J. Foraminiferal Res., 18:250-266.

Matsunaga, T., 1963. Benthic smaller foraminifers from the oil fields of northern Japan. Sci. Rep. Tohoku Univ., Ser. 2, 35:67-122.

Nakaseko, K., and Sugano, K., 1973. Neogene radiolarian zonation in Japan. Chishitsugaku Ronshu, 8:23-33. (in Japanese)

Otofuji, Y., Hayashida, A., and Torii, M., 1985. When was the Japan Sea opened? Paleomagnetic evidence from southwest Japan. In Nasu, N., Uyeda, S., Kushiro, I., Kobayashi, K., and Kagami, H. (Eds.), Formation of Active Ocean Margins: Tokyo (Terra Publ.), 551-566.

Otofuji, Y., Matsuda, T., and Nohda, S., 1985. Paleomagnetic evidence for the Miocene counterclockwise rotation of Northwest Japan-rifting process of the Japan arc. Earth Planet. Sci. Lett., 75:265-277.

Prell, W. L., Imbrie, J., Martinson, D. G., Morley, J. J., Pisias, N. G., Shackleton, N. J., and Streeter, H. F., 1986. Graphic correlation of oxygen isotope stratigraphy application to the late Quaternary. Paleoceanography, 1:137-162.

Tamaki, K., Pisciotto, K., Allan, J., et al., 1990. Proc. ODP, Init. Repts., 127; College Station, TX (Ocean Drilling Program).

Yamanoi, T., 1989. Marine palynological zones and events in Japan. Proc. Int. Symp. Pacific Neogene Continental and Marine Events. Nanjing Univ. Press, 83-91.

Date of initial receipt: 17 December 1991

Date of acceptance: 28 February 1992

Ms 127/128B-151 